\title{
Identification of rye chromosomes by flow cytogenetics
}

\author{
O. G. Alkhimova, O. V. Zimina \\ Institute of Molecular Biology and Genetics, NAS of Ukraine \\ 150, Akademika Zabolotnoho Str., Kyiv, Ukraine, 03680 \\ o.g.alkhimova@imbg.org.ua
}

'The Catchers in the rye'

The karyotype of the cultivated rye (Secale cereale) is one of the complex plant genomes whose chromosomes are difficult to discriminate because of their similar size. Aim. The purpose of this study is to reveal the chromosome variable sites using DNA repetitive sequences as probes and to define a possibility of sorting rye chromosomes. Methods. Flow cytometry analysis and karyotyping, chromosome sorting, fluorescence in situ hybridization and microscopy. Results. Different distribution of repetitive DNA sites between two rye accessions was demonstrated and an ability to sort chromosome 1 in the 'Zhyttedaine' rye variety was shown. This is the second case when chromosome $1 \mathrm{R}$ was sorted by flow cytometry in S. cereale. Conclusions. The present study revealed chromosome polymorphisms of microsatellite sequence GAA in accessions and the potential of chromosome sorting in S. cereale varieties. We also identified sequence elements including microsatellites and classic satellites which can be utilized for future research and in rye breeding.

Ke y w o r d s: subtelomeric heterochromatin, satellite repeats, Secale cereale, chromosome sorting, fluorescence in situ hybridization

\section{Introduction}

A distinctive feature of the rye (Secale cereale) chromosomes is the presence of massive blocks of subtelomeric heterochromatin, the size of which correlates with the copy number of tandem repeats $[1,2]$. Subtelomeric, or telomere-associated, rye heterochromatin is enriched with a few multi-copy tandemly organized DNA families [3, 4]. Two of them, pSc200 and pSc250, have monomer lengths of
379 and $571 \mathrm{bp}$, respectively, and belong to classic tandem repeats, or satellite DNA [1]. We previously demonstrated by double target fluorescence in situ hybridization (FISH) that both sequences occur together and give mostly overlapping strong signals at the ends of most arms of the metaphase chromosomes. We also estimated the length, composition and distribution of monomers within the individual terminal DNA arrays on separate rye chromosomes for $S$. cereale by performing dual-

(C) 2017 O. G. Alkhimova et al.; Published by the Institute of Molecular Biology and Genetics, NAS of Ukraine on behalf of Biopolymers and Cell. This is an Open Access article distributed under the terms of the Creative Commons Attribution License (http://creativecommons.org/licenses/by/4.0/), which permits unrestricted reuse, distribution, and reproduction in any medium, provided the original work is properly cited 
label FISH with authentic telomeric and two subtelomeric probes, $\mathrm{pSc} 200$ and $\mathrm{pSc} 250$, to extended DNA fibers [1].

In human, the identification of individual chromosomes is facilitated by using GTGtechnique and/or bivariate analysis after staining with AT- and GC-binding fluorochromes. Due to similar size of all 14 rye chromosomes that cannot be resolved by flow sorting, the use of microsatellite loci, with significant levels of polymorphism, have been adopted to produce detailed chromosome maps $[5,6]$. Nevertheless, flow karyotyping and chromosome sorting would facilitate the analysis of the complex rye genome including construction of chromosome-specific BAC libraries and next-generation sequencing. Chromosome sorting would allow determination of telomere lengths for each particular chromosome separately. One of the most promising applications of flow-sorted chromosomes is the construction of chromosome-specific libraries, which can be used for different purposes [7]. Here, we compare the rye accessions chromosome polymorphism using flow sorting and fluorescence in situ hybridization with probes for chromosome identification.

\section{Materials and Methods}

\section{Plant material}

The material analysed consisted of three cultivars of rye (Secale cereale), Selgo (IEB collection), Imperial seeds were kindly provided by S. M. Reader (John Innes Centre, Norwich, UK) and Zhyttedaine (IMBG collection).

Root tips were pretreated in ice-cold water for 24-28 $\mathrm{h}$ and fixed in ethanol-acetic acid (3:1). After preparation the slides were checked carefully by phase contrast. The karyotypes were established by using at least 20 high quality metaphase chromosome spreads from at least 5 slides made from 5-7 seeds of each genotype.

\section{DNA probes and labelling}

Two non-homologous subtelomeric repetitive sequences, pSc200 (accession number Z50039.1) and pSc250 (accession number Z50040.1), were cloned from $S$. cereale. For in situ hybridization, the clones were labelled with digoxigenin-11-dUTP (Roche) and biotin11-dUTP (Roche) by the polymerase chain reaction (PCR). FISH probe for 45S rDNA was obtained by labelling the pTa71 DNA clone containing the 26S rRNA gene with digoxigenin-11-dUTP. 5S rDNA is contained in the pTa794 probe prepared from 400 bp insert of a part of the 5S rRNA gene and labelled with biotin-16-dUTP (Roche). Both probes were labelled by PCR using M13 direct and reverse primers.

\section{Preparation of chromosome suspensions} and flow cytometry

The chromosome suspension from synchronized root tip meristems was prepared as described by Vrana et al. [7, 8]. Briefly, the major stages of procedure included cell cycle synchronization and accumulation of metaphases in root tips using hydroxyurea treatment solution $(2.5 \mathrm{mM})$. Formaldehyde fixative of final concentration $2 \%$ was used. Duration of hydroxyurea treatment $(18 \mathrm{~h})$, recovery time ( $7 \mathrm{~h}$ for Selgo, $8 \mathrm{~h}$ for Imperial and $10 \mathrm{~h}$ for Zhyttedaine) and treatment with ice water ( $20 \mathrm{~h}$ on average) were estimated for each accession individually. Preparation of mitotic 
chromosomes solution followed by flow cytometric analysis and identification of sorted chromosomes $[8,9]$. Estimation of chromosome purity was carried out by FISH. Chromosome content of the peaks was determined after double FISH on sorted chromosomes using various combinations of probes for $\mathrm{pSc} 200$ and $\mathrm{pSc} 250$ repeats, GAA microsatellite, and 5S rDNA.

\section{Fluorescence in situ hybridization and microscopy}

The methods for chromosome slide preparation and in situ hybridization were adapted from the protocols developed by Schwarzacher and Heslop-Harrison [10]. Briefly, root tips of seedlings were fixed, partially digested with $1 \%$ cellulase and $1 \%$ pectinase enzymes for $60 \mathrm{~s}$ at $37^{\circ} \mathrm{C}$, and cells were spread on slides. The probes were labelled, denatured $\left(70{ }^{\circ} \mathrm{C}\right.$ for $5 \mathrm{~min}$ ), applied onto the slides, then probes and slides were denatured together at $80{ }^{\circ} \mathrm{C}$ for $2 \mathrm{~min}$. The concentration of formamide in the hybridization mixture, containing $2 \times \mathrm{SSC}$, was 40 or $50 \%$. After the overnight hybridization at $37^{\circ} \mathrm{C}$, the slides were washed, with the most stringent wash at $42{ }^{\circ} \mathrm{C}$ in $20 \%$ formamide, $0.1 \times \mathrm{SSC}$. The hybridization signals were detected using antidigoxigenin conjugated to fluorescein isothiocyanate (Roche). Sites of probe hybridization to chromosomes were detected with antidigoxigenin-FITC antibodies (fluorescing green) or Cy3-conjugated streptavidin (red). After detection, the slides were washed, counterstained with 4'6-diamidino-2-phenylindole (DAPI), and analysed with appropriate filters on a Leica epifluorescence microscope. The slides also were evaluated using Olympus BX 60 microscope.

\section{Results}

\section{Chromosome sorting}

The flow cytometric analysis indicated that the composite peak of 'Selgo' was comprised of chromosomes 1R-7R (Fig. 1 A). Flow karyotype of 'Imperial' contains two peaks representing the chromosomes of rye $2 \mathrm{R}-7 \mathrm{R}$ whereas the shoulder contains the chromosome 1R (Fig. 1 B). We have identified this chromosome after sorting procedure using FISH with two probes, subtelomeric pSc250 and pTa71 for $45 \mathrm{~S}$ rDNA locus which defined the NOR (Nucleolus Organizing Region). To date, rye 'Imperial' was the only $S$. cereale variety, the flow karyotype of which differed from this typical pattern and the peak of chromosome $1 \mathrm{R}$ was clearly separated from the composite peak, and the chromosome could be sorted [9].

The flow cytometric analysis of metaphase chromosomes isolated from rye 'Zhyttedaine', resulted in flow karyotype also consisting of two composite peaks (Fig. 2 A). The chromosome $1 \mathrm{R}$ being the smallest from the 'Imperial' chromosome set was considered as the only one, which can be sorted individually. We showed for the first time the second accession 'Zhyttedaine', the chromosome of which could be sorted allowing the discrimination of the chromosome 1 in rye karyotype. The flowsorted chromosome 1R after double FISH with a FITC-labelled probe for 45S rDNA (the probe highlights NOR in yellow-green colour) and Cy3-labelled probe for rye specific repeat pSc250 (red colour) is shown on the Fig. 2. The chromosomes were counterstained with DAPI (blue colour) (Fig. 2 B).

Flow karyotypes obtained after analysis of DAPI stained chromosomes in $S$. cereale easy 
$\boldsymbol{A}$

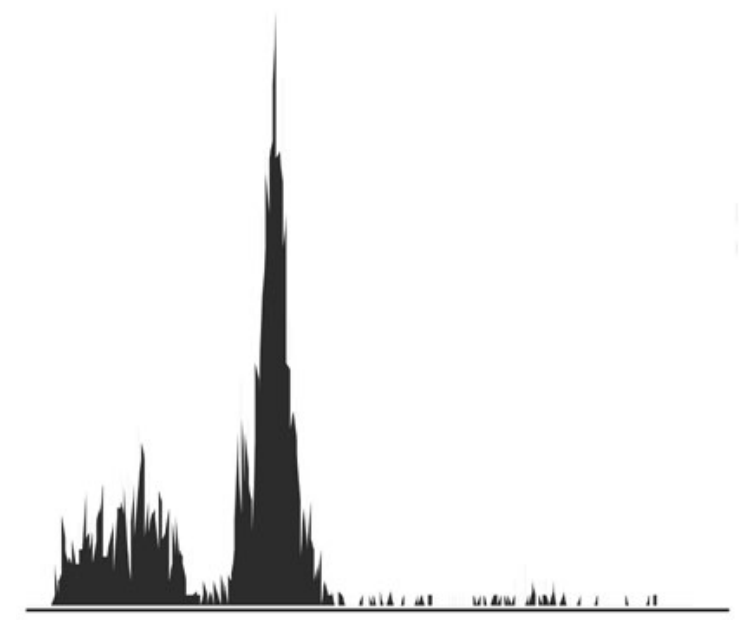

B

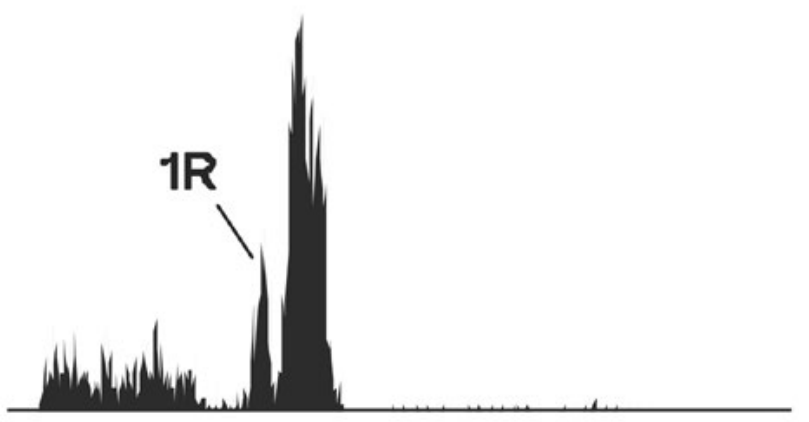

Fig. 1. Histogram of relative fluorescence intensity (flow karyotype) obtained after flow cytometric analysis of DAPI stained chromosome suspension of rye lines. Composite peak of 'Selgo' is comprised of chromosomes $1 \mathrm{R}-7 \mathrm{R}(A)$. The karyotype of 'Imperial' contains two peaks representing the chromosomes of rye $2 \mathrm{R}-7 \mathrm{R}$ and a peak of the chromosome $1 \mathrm{R}(B)$. The peak of chromosome $1 \mathrm{R}$ is clearly discernible and chromosomes can be easily sorted.
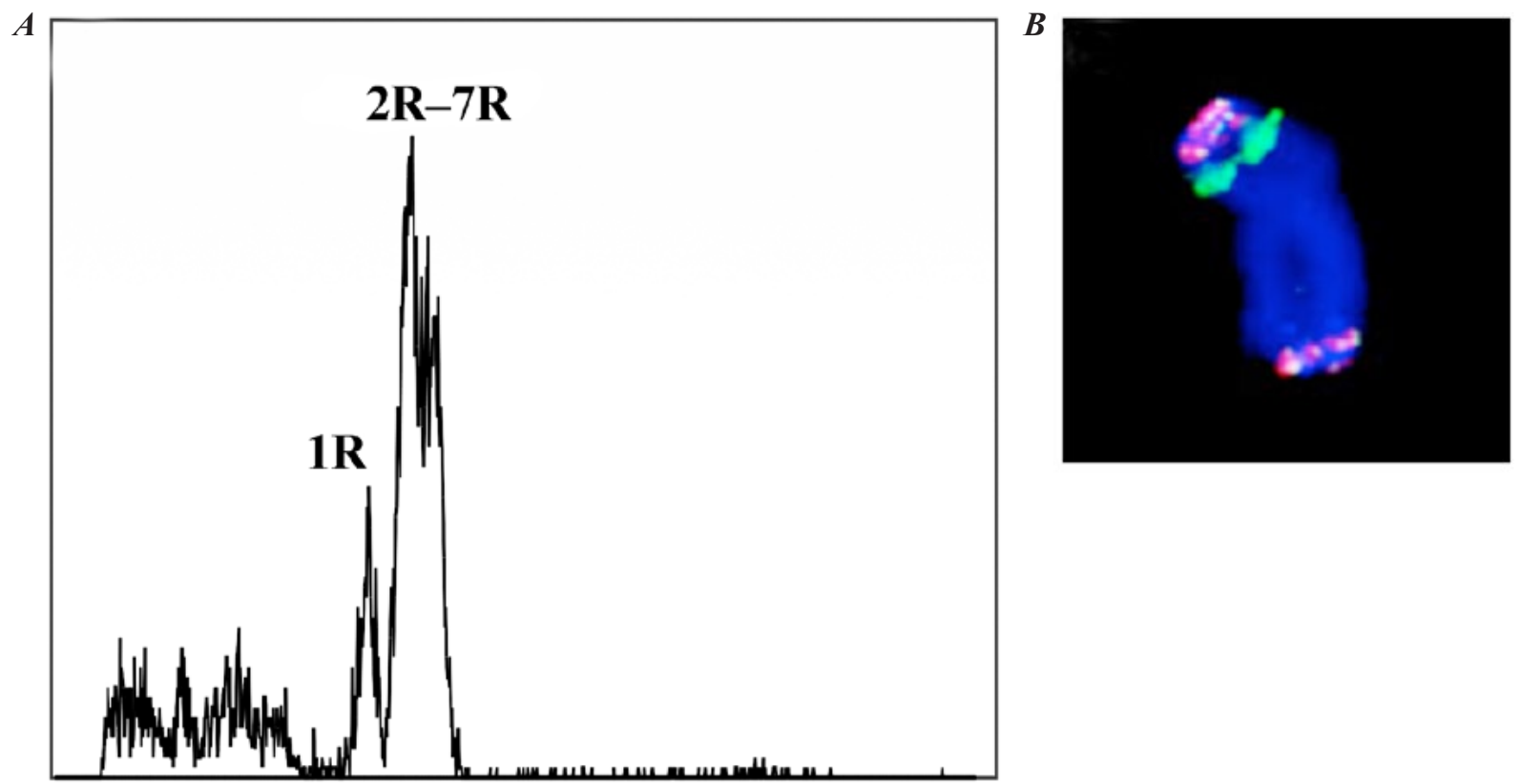

Fig. 2. Flow karyotyping of rye. (A) The flow karyotypes of 'Imperial' and 'Zhyttedaine' $(2 n=2 X=14)$ comprise a large composite peak representing the chromosomes $2 \mathrm{R}-7 \mathrm{R}$, and a peak representing the chromosome $1 \mathrm{R}$. $\mathrm{X}$-axis: relative DAPI fluorescence, Y-axis: number of events. (B) The figure shows an example of the sorted chromosome 1 after DAPI staining and after FISH with probes for the pSc250 repeat and pTa71 for 45S rDNA. 
discriminate the $1 \mathrm{R}$ chromosomes and allow the sorting of great amount with a high purity, more than $90 \%$, that was confirmed by FISH. In both accessions, the $1 \mathrm{R}$ chromosomes formed a separate peak on the flow karyotype which allowed their sorting.

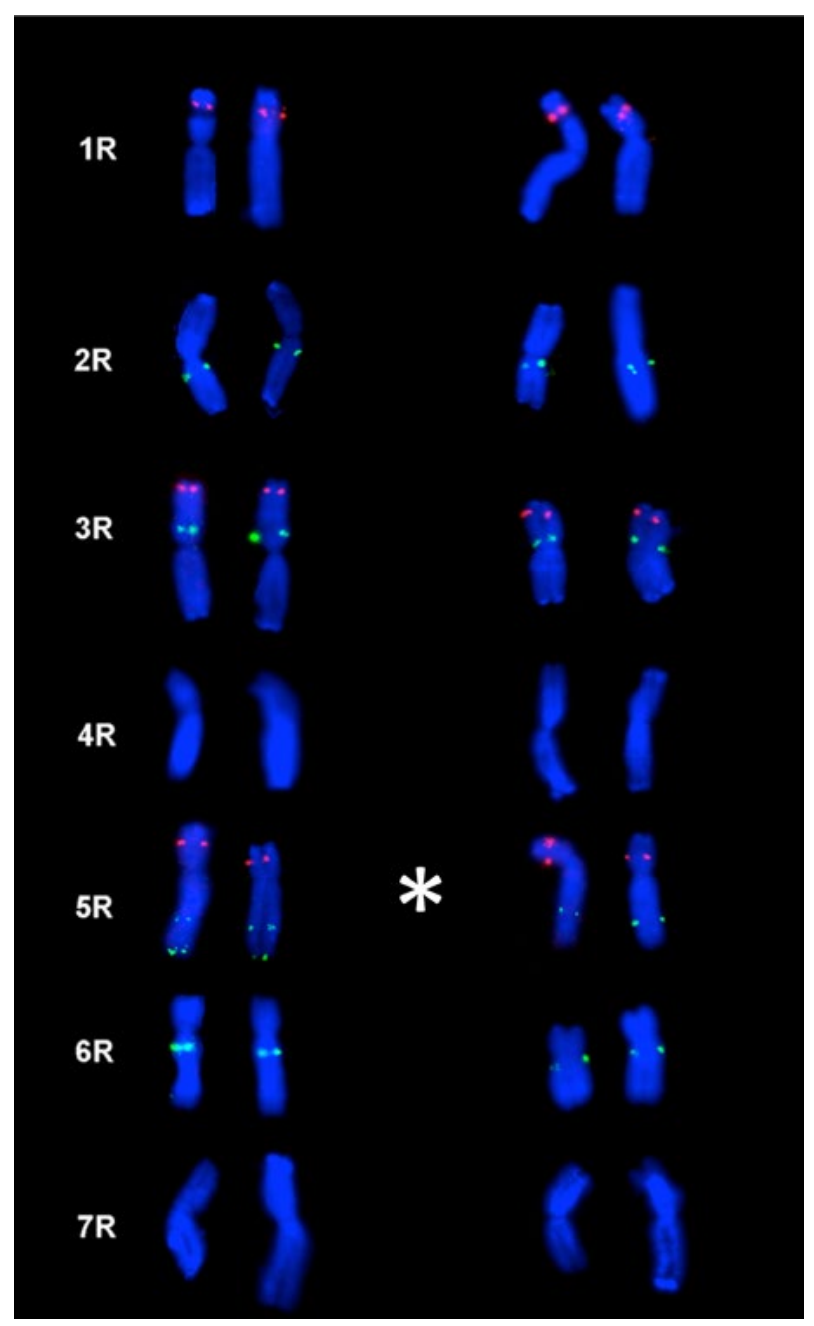

Fig. 3. Fluorescence in situ hybridization of GAA repeat and $5 \mathrm{~S}$ ribosomal DNA on rye chromosomes, $S$. cereale. Double FISH with a FITC-labelled probe for GAA microsatellite (the probe highlights ribosomal DNA in green colour) and Cy3-labelled probe for $5 \mathrm{~S}$ rDNA repeat (red colour). The chromosomes were counterstained with DAPI (blue colour).

\section{Chromosome location of $G A A$ and $5 S$ rDNA repeats}

FISH with GAA microsatellite and 5S rDNA probes revealed polymorphisms in distribution of the GAA repeats on the long arm of chromosome 5 between two rye accessions, 'Selgo' and 'Zhyttedaine' (Fig. 3).

Three chromosomes, namely $1 \mathrm{R}, 3 \mathrm{R}$ and $5 \mathrm{R}$ possess clear $5 \mathrm{~S}$ rDNA signals on short chromosome arms in both accessions. By contrast, GAA repeat recognizes microsatellite loci differences and enables the discrimination of chromosome pairs in S. cereale.

\section{Discussion}

\section{Chromosome localization of repeats and} intervarietal chromosome polymorphisms

Previously, refereeing the description of the rye chromosome nomenclature of Sybenga [5], we compared the karyotypes of three rye varieties, Petkus, Imperial and Onohoiskaya [11]. The distribution of both tandem repeats, pSc200 and pSc250, on the chromosomes of $S$. cereale showed that in all three varieties, the chromosomes 1R (carrying the nucleolus organizing region), 3R, 5R and $6 \mathrm{R}$ yielded no intervarietal differences in the location and number of $\mathrm{pSc} 200$ sites. This probe gave strong signals at the ends of both chromosome arms with variable intensities corresponding to the size of heterochromatic bands. Intervarietal polymorphism in distribution of pSc200 was revealed on the chromosomes $2 \mathrm{R}$ and 4R. While Petkus was labelled with pSc200 on all chromosome arms, a hybridization signal was absent from the long arm of both homologues of Imperial chromosome 4R. The long-range organization of tandem arrays 
was reported by us previously [1]. The rye varieties, Petkus, Imperial and Onohoiskaya, showed polymorphism for the presence and the size of the pSc200 in situ hybridization signals on the chromosome pairs, 2R, 4R and $7 \mathrm{R}$, and the pSc250 signals on chromosomes, $5 R, 6 R$ and $7 R$. Differences in the distribution of chromosome polymorphism imply that intervarietal changes in these highly repetitive DNA families occurred independently, despite their juxtaposition or even overlapping locations in subtelomeric heterochromatic regions [3]. The organization of tandem repeats in high-ordered tandem arrays, localization at the ends of all rye chromosomes by FISH mapping on metaphase chromosomes and absence in wheat genome made them the reliable markers for the physical mapping of the terminal regions in varieties, closely related relatives of $S$. cereale. The diverse patterns of site hybridization for these DNA families were demonstrated in two Dasypyrum species that evidenced the independent origin and confirm their status as separate evolution units [4]. The results are an important evidence due to the changes observed in karyotypes.

\section{Identification of Secale cereale chromo- somes and rye genome analysis}

In situ hybridization with two non-homologous highly repetitive DNA sequences, pSc200 and pSc250, showed chromosome-specific localization allowing the identifcation of the majority of rye chromosome arms $[1,11]$. The additional sites for chromosome identification were demonstrated using GAA microsatellite repeat and pTa794 probe, the fragment of $5 \mathrm{~S}$ ribosomal DNA. Since the chromosomes 1R and 3R have similar pattern of in situ hybridi- zation with pSc200, pSc250 and pSc119, altogether these DNA sequences allow discrimination of all $S$. cereale chromosomes in Selgo and Zhyttedaine accessions (Fig. 3). Unlike Selgo chromosomes, newly derived accession Zhyttedaine did not show polymorphism for the presence and size of GAA signals on the chromosome 5R (Fig. 3).

The rye genome analysis at molecular level is impeded because of its large size $(1 \mathrm{C}=$ $7900 \mathrm{Mbp}$ ), i.e. 1.4 times larger than that of the diploid ancestors of hexaploid bread wheat. Repeats may equal more than $90 \%$ of the rye genome. The analysis may be facilitated by the availability of subgenomic (chromosome specific) DNA libraries. The chromosome 1R represents not only significant part of the rye genome, but also a range of economically important accessions of the wheat genomes [12].

The repetitive DNA sequence evolution may be accelerated when an organism is subjected to some stress: different environmental factors, wide hybridization, in vitro cultivation. The suggested tendency of cereal genomes to expand in size over evolutionary time has been attributed mainly to retrotransposons [3, 13]. However, it is likely that the expansion of highly repetitive tandemly organized DNA sequences also contribute to this process, at least as much as retrotransposons, because of their high copy number $[1,2]$. Basically, the array homogenization and DSB-related repair mechanisms generate the increased structural heterogeneity $[2,14]$. When investigating the positioning of chromosomes during the cell cycle in live mammalian cells, a combined experimental and computational approach has shown a striking order of chromosomes throughout mitosis $[15,16]$. Based on the tracking of labelled chromosomes 
during chromosome segregation, these results demonstrate that the global chromosome positions were heritable, that is the sister chromatid separation transmits the positions to the next cell generation.

\section{Conclusions}

All chromosomes have definite basic features, but each individual chromosome differs by the size and molecular organization of separate repetitive DNA arrays. The isolation of particular plant chromosomes by flow sorting was developed and optimized in the laboratory of Prof. Dolezel (Institute of Experimental Botany, Olomouc, Czech Republic) [8]. The procedure allows identification of the alien rearranged chromosomes on the host background and even discrimination of the chromosomes differed by telomere-associated DNA due to fine tune lazar capacity. Intervarietal chromosome polymorphisms allow the creation of plant models for investigation of significant processes in plant genetics such as chromosome segregation and recombination, somatic chromosome reduction or assortment [17]. The constructed by now the chromosome-specific rye libraries facilitate deciphering and interpretation of the complex rye genome. The use of various rye accessions with a diverse homologous chromosomes banding is an excellent system approach to research the somatic segregation phenomenon.

\section{Acknowledgements}

We thank Dr S. M. Reader (John Innes Centre, UK) for the seeds of Imperial and Dr Marie Kubalakova (IEB, Czech Republic) for chromosome sorting and FISH on Selgo chromosomes.
This work was partially supported by the European Community's Framework Programme FP7/2007-2013 (FP7-212019).

\section{REFERENCES}

1. Alkhimova OG, Mazurok NA, Potapova TA, Zakian SM, Heslop-Harrison JS, Vershinin AV. Diverse patterns of the tandem repeats organization in rye chromosomes. Chromosoma. 2004; 113(1): 42-52.

2. Evtushenko EV, Levitsky VG, Elisafenko EA, Gunbin KV, Belousov AI, Šafár J, Doležel J, Vershinin $A V$. The expan-sion of heterochromatin blocks in rye reflects the co-amplification of tandem repeats and adjacent transposable elements. BMC Genomics. 2016; 17:337.

3. Vershinin AV, Alkhimova AG, Heslop-Harrison JS, Potapova TA, Omelianchuk N. Different patterns in molecular evolution of the Triticeae. Hereditas. 2001;135(2-3):153-60.

4. Vershinin AV, Alkhimova OG, Heslop-Harrison JS. Molecular diversification of tandemly organized DNA sequences and heterochromatic chromosome regions in some triticeae speciess. Chromosome Res. 1996; 4(7):517-25.

5. Sybenga J. Cytogenetics in Plant Breeding. - Berlin: Springer, 1992; $469 \mathrm{p}$.

6. de Santana Costa MG, Leite BSF, Loges V, Silva EBC, da Costa AS, Guimaraes WNR, Brasileiro-Vidal AC. Chromosome markers confirm origin of Heliconia hybrids and triploids. Euphytica. 2016;212(3):501-14.

7. Vrána J, Kubaláková M, Simková H, Cíhalíková J, Lysák MA, Dolezel J. Flow sorting of mitotic chromosomes in common wheat (Triticum aestivum L.). Genetics. 2000;156(4):2033-41.

8. Vrána J, Cápal P, Cíhaliková J, Kubaláková M, Doležel J. Flow Sorting Plant Chromosomes. Methods Mol Biol. 2016;1429:119-34.

9. Kubaláková $M$, Valárik $M$, Barto J, Vrána J, Cíhaliková J, Molnár-Láng M, Dolezel J. Analysis and sorting of rye (Secale cereale L.) chromosomes using flow cytometry. Genome. 2003;46(5):893-905.

10. Schwarzacher T, Heslop-Harrison JS. Practical in situ Hybridization. Oxford: BIOS; 2000; 250 p. 
Identification of rye chromosomes by flow cytogenetics

11. Alkhimova AG, Heslop-Harrison JS, Shchapova AI, Vershinin $A V$. Rye chromosome variability in wheatrye addition and substitution lines. Chromosome Res. 1999;7(3):205-12.

12. Bartos J, Paux E, Kofler R, Havránková M, Kopecký D, Suchánková P, Safár J, Simková H, Town CD, Lelley T, Feuillet C, Dolezel J. A first survey of the rye (Secale cereale) genome composition through BAC end sequencing of the short arm of chromosome 1R. BMC Plant Biol. 2008;8:95.

13. Lelley T, Eder C, Grausgruber H. Influence of 1BL.1RS wheat-rye chromosome translocation on genotype by environment interaction. J Cereal Sci. 2004; 39(3):313-20.

14. Plohl M, Luchetti A, Mestrović N, Mantovani B. Satellite DNAs between selfishness and functionality: structure, genomics and evolution of tandem repeats in centromeric (hetero)chromatin. Gene. 2008;409(1-2):72-82.

15. Gerlich D, Beaudouin J, Kalbfuss B, Daigle N, Eils $R$, Ellenberg $J$. Global chromosome positions are transmitted through mitosis in mammalian cells. Cell. 2003;112(6):751-64.

16. Sharma A, Wolfgruber TK, Presting GG. Tandem repeats derived from centromeric retrotransposons. BMC Genomics. 2013;14:142.

17. Zimina OV, Parii MF, Alkhimova OG. Loss of heterozygosity at individual loci in Arabidopsis thaliana regenerants cultured with para-fluorophenylalanine. Cytol Genet. 2016; 50(5):278-84.

\section{Ідентифікація хромосом жита методом флуоресцентної проточної цитометрії}

О. Г. Алхімова, О. В. Зіміна

Каріотип жита посівного (Secale cereale) розглядається як один із складних рослинних геномів, хромосоми якого важко відрізнити через однаковий розмір хромосом. Мета. Виявлення варіабельних ділянок хромосом 3 використанням повторюваних послідовностей ДНК в якості зондів і визначення можливості сортування хромосом у сортів жита. Методи. Проточна цитометрія і каріотипування, сортинг хромосом, флуоресцентна гібридизація in situ та мікроскопія. Результати. Показано різний розподіл повторюваних послідовностей
ДНК між двома сортами жита і здатність до сортингу хромосоми 1 у жита 'Життєдайне'. Вдруге продемонстровано можливість сортувати хромосому $1 \mathrm{R}$ методом проточної цитометрії у жита $S$. cereale. Висновки. Дослідження виявило хромосомний поліморфізм мікросателітної послідовності GAA у сортів жита і потенційну можливість сортингу хромосом у Secale, i показало, що мікросателіти і класичні сателіти можуть бути використані у подальших дослідженнях, а також в селекції жита.

К л юч о в і с л о в а: субтеломерний гетерохроматин, сателітні повтори, Secale cereale, сортинг хромосом, флуоресцентна гібридизація in situ

\section{Идентификация хромосом ржи методом флуоресцентной проточной цитометрии}

\section{О. Г. Алхимова, О. В. Зимина}

Кариотип ржи посевной (Secale cereale) рассматривается в качестве одного из самых сложных растительных геномов, хромосомы которого трудно различить ввиду одинакового размера. Цель. Выявление вариабельных участков хромосом с помощью повторяющихся последовательностей ДНК в качестве зондов и определение возможности сортинга хромосом у сортов ржи. Методы. Проточная цитометрия и кариотипирование, сортинг хромосом, флуоресцентная гибридизация in situ и микроскопия. Результаты. Различное распределение повторяющихся последовательностей ДНК продемонстрировано у двух сортов ржи и показана возможность сортинга хромосомы 1 у ржи 'Життедайне'. Это второй случай, когда хромосома $1 \mathrm{R}$ была сортирована методом проточной цитометрии у ржи S. cereale. Выводы. Настоящее исследование выявило хромосомный полиморфизм микросателлитной последовательности GAA у сортов ржи и потенциальную возможность сортинга хромосом у Secale и показало возможность использования микросателлитов и классических сателлитов для дальнейших исследований, а также в селекции ржи.

Кл юч е в ы е с л о в а: субтеломерный гетерохроматин, сателлитные повторы, Secale cereale, сортинг хромосом, флуоресцентная гибридизация in situ.

Received 05.01.2017 